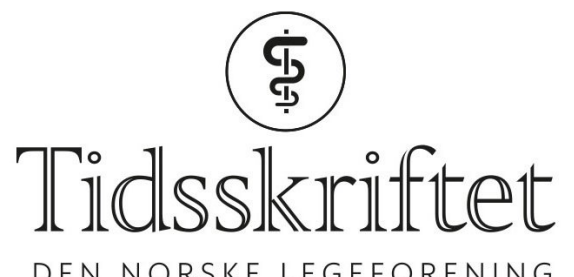

\title{
Et spørsmål om estetikk
}

REPORTASJE

IRENE THORESEN RØNOLD

E-post: irene.thoresen.ronold@tidsskriftet.no Tidsskriftet

Kritiske røster mener det han gjør ikke er forenlig med legegjerningen. Men Karim Sayed føler seg som helsepersonell når han er på jobb.

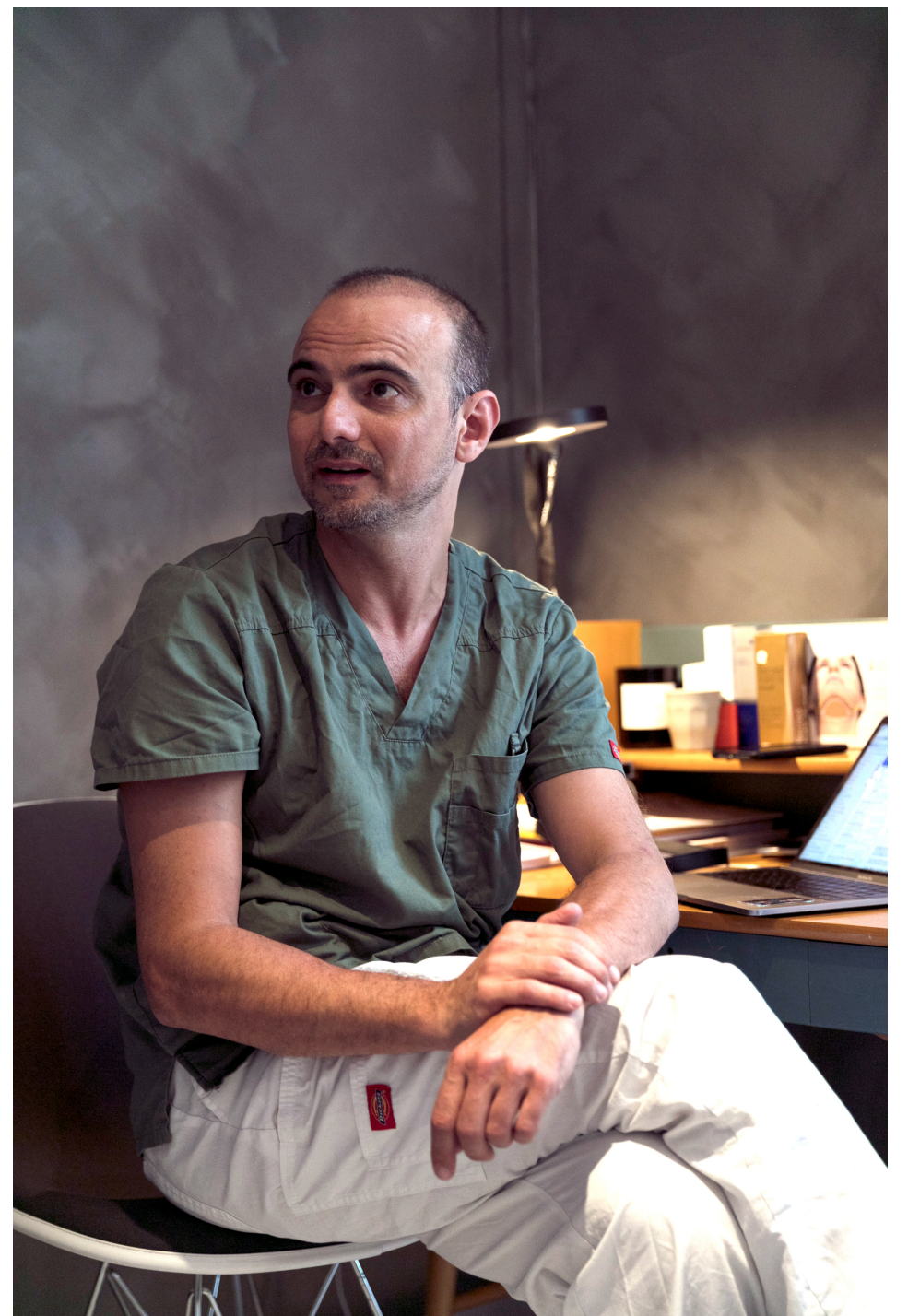

Karim Sayed mener etikken er viktig i estetisk medisin. - Disse prosedyrene kan tross alt gi komplikasjoner. Og vi redder ikke liv. Det gir oss et ekstra stort ansvar, sier han. Alle foto: Christian 
Om den løse huden på magen har plaget henne? Svaret på det er ja. De siste årene har hun ikke en gang villet bade ute sammen med barna. Nå har kvinnen tatt plass på en behandlingsbenk hos Senzie Medispa i Oslo sentrum.

Hun har kneppet opp de lyse jeansene og rullet opp genseren, slik at magen er bar. For å beskytte øynene har hun fått låne et par mørke briller - spesialbriller for laserbehandling, får vi forklart. Nå ligger hun helt stille mens 43 år gamle Karim Sayed, medisinsk ansvarlig ved klinikken, varmer opp huden på magen hennes ved hjelp av et laserapparat.

- Jeg synes dette har blitt veldig mye bedre allerede. Vi trenger nesten ikke flere behandlinger etter dette, sier Sayed.

Det er andre gang kvinnen besøker klinikken for å få strammet opp huden på magen. Flere svangerskap har gjort sitt. På førbildene kan man se hvordan huden liksom hang ned foran navlen.

- Det er jo vanlig at huden på magen blir slapp etter svangerskap. Men hvis man synes det er veldig sjenerende, kan det være greit å gjøre noe med det, sier Sayed, henvendt til kvinnen, før han bytter laser.

- Nå går vi over til den som skyter litt. Går det bra?

Les også: Rådet for legeetikk om etikken i estetikken

\section{Ikke så overfladisk}

Det har gått ti år siden Karim Sayed hadde sitt første møte med estetisk medisin. Da var han nyutdannet allmennlege og aktiv musiker - i løpet av karrieren har han spilt med blant andre A-ha, Madrugada, og Bigbang - samtidig som han jobbet på Gatehospitalet og tok vakter på Oslo legevakt.

- Etter hvert tenkte jeg: «hva kan jeg gjøre i stedet, som er fleksibelt?». Botox hadde akkurat begynt å bli populært, og en kollega av meg hadde begynt med det. «Bli med meg, jeg kan lære deg», sa kollegaen.

Den unge legen reagerte først med skepsis.

- Jeg tenkte at det bare var tull. Man setter en sprøyte og fjerner noen rynker - so what? Men det viste seg at det er veldig faglig interessant. Man må forstå anatomien i ansiktet og hvordan musklene fungerer sammen. Dessuten har jeg alltid vært interessert i form, kunst og design, sier Sayed.

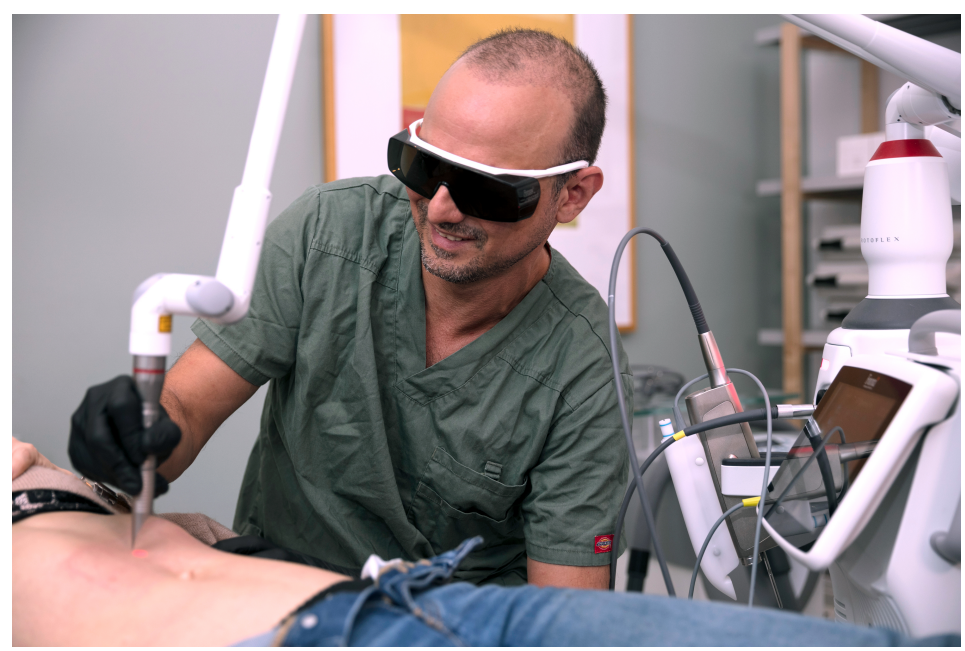

- Mennesker har alltid vert opptatt av hvordan de ser ut.Jeg tror ikke noe på at vi skaper et behov når vi driver med dette, sier Karim Sayed.

I starten så han på botox- og fillerbehandlingene som en ekstrajobb - noe som var greit betalt, fleksibelt og passet godt med livet ellers. Så kom lysten til å sette seg bedre inn i 
feltet. Sayed anslår selv at han har brukt flere hundre timer på kurs og videreutdanninger innen feltet, både i Italia, England og USA. I dag jobber han 50 \% som medisinsk ansvarlig og overlege på Gatehospitalet og for Frelsesarmeens Rusomsorg, og 50 \% med estetisk medisin.

- Det gir en fin variasjon. Jeg hadde ikke fortsatt med kosmetisk medisin hvis jeg ikke syntes det var gøy eller spennende. Det er mindre overfladisk enn jeg trodde det skulle være, kommenterer Sayed, og utdyper:

- Mange har ting som plager dem, og som man godt kan forstå. Jeg merker fort når noe skurrer, for eksempel hvis det er en veldig ung jente som ønsker seg veldig store lepper. Men det har blitt færre av de situasjonene enn jeg trodde. Jeg føler meg som helsepersonell når jeg er på jobb, sier han.

Les også: Legeprofesjonens (kosm)etiske problem

\section{Marked i vekst}

Sayed opererer i et marked i eksplosiv vekst. Tall fra Apotekforeningen viser at det i 2017 ble solgt nesten 18300 pakninger botulinumtoksin A fra norske apotek. Det er nesten en tredobling siden 2010, da det ble solgt 64 oo pakker. Selv om stoffet har hatt $\emptyset \mathrm{kt}$ medisinsk bruk de siste årene, er det sannsynlig at en god del av økningen skyldes nordmenns ønske om å holde rynkene på avstand.

- Mange føler at de ser trøtte, slitne eller sure ut. De fleste som kommer hit har ikke problemer med å eldes eller få rynker, men de liker ikke å gå rundt og se sinte ut, sier Sayed.

Han kan fortelle at Botox er den klart mest populære behandlingen de tilbyr.

Fillerbehandling, som skal gi økt volum og form til leppe og kinnben, er en god nummer to. Ifølge Sayed er kundene vanlige folk i alle aldre, med ulike problemer de ønsker å ta tak i. I tillegg til laserbehandlingen han gjennomførte på formiddagen, skal han i dag behandle en pasient som er plaget med stramme arr i ansiktet etter at å ha blitt operert for kreft.

Han er ikke i tvil om at estetisk medisin er kommet for å bli.

- Jeg er uenig med de som sier at helsepersonell ikke bør drive med dette. Det er ekstremt viktig med kompetente behandlere. Og mennesker har alltid vært opptatte av hvordan de ser ut. Jeg tror ikke noe på at vi skaper et behov når vi driver med dette, sier Sayed.

Akkurat det er det imidlertid ikke alle som er enige i.

\section{Kritiske røster}

For er det egentlig greit at leger driver med estetisk medisin? Debatten har gått siden spørsmålet ble reist i en kronikk i Aftenposten av lege og forsker ved Senter for medisinsk etikk ved Universitetet i Oslo, Henrik Vogt, og allmennlege Andreas Pahle.

- Å være profesjonell handler om å sette grenser for hva vi som leger skal gjøre. Tradisjonelt er medisin en profesjon som jobber med sykdom. Dette er noe annet, nemlig å forbedre allerede friske mennesker, sier Vogt.

I kronikken kom Vogt og Pahle med krass kritikk av både plastikkirurger og leger som tilbyr behandlinger som Botox og fillere. Sammen med Norsk forening for allmennmedisin (NFA) ba de i etterkant Rådet for legeetikk om å ta stilling til om estetisk medisin er forenlig med legegjerningen.

- Disse legene tilbyr behandling og tjenester som gjør at forholdet til utseende i samfunnet ellers endres. Det er markedsdrivende. Å hevde at misnøyen er der uansett, er en uholdbar påstand. Denne praksisen er med på å skape et marked av misnøye over eget utseende, som leger igjen tjener penger på, argumenterer Vogt.

- Legene skaper vel ikke dette markedet alene?

- Nei, men det er likegyldig. Legene må selv ta ansvar for det de gjør, som helt nødvendige, muliggjørende aktører i samfunnsutviklingen, fastslår Vogt. 
Han legger til at det er uklart hva pasienter vil få ut av kosmetiske behandlinger.

- Ettersom det er snakk om friske mennesker, er det uklar indikasjon medisinsk sett. Det er altså uklart hva man kan få ut av det. Og det vil kunne oppstå skader og kostnader for dem det gjelder, og tapte muligheter for å behandle problemet på en annen måte, sier Vogt.

- Hva tenker du på da?

- Et menneske som er veldig misfornøyd med utseendet sitt, kan trenge andre måter å behandle det på. Mennesker som tilbys kirurgi, får ikke denne muligheten, sier Vogt.

Les også: Et marked av uhelse

\section{Utseende betyr noe}

- Jeg ser med mine egne øyne hvor mange som får det bedre. Det er lett å stå utenfor og si at dette arbeidet er meningsløst. Men når jeg ser hvor mye glede det gir pasientene mine, gir det mening for meg, sier Sayed.

Samtidig er han enig i at det for enkelte pasienter ikke er medisinsk behandling som er løsningen. Han mener en forutsetning for å drive med estetisk medisin er at du vet hvem du kan behandle.

- Noen mennesker er kronisk misfornøyd. De er det ikke riktig å behandle. Det er tvert imot etisk veldig viktig å la være. Disse prosedyrene kan tross alt gi komplikasjoner, og vi redder ikke liv. Disse pasientene er ikke syke. Det gir oss et ekstra stort ansvar, spesielt med tanke på risiko for komplikasjoner, sier Sayed.

Han får støtte fra Bjørn Tvedt, plastikkirurg og styremedlem i Norsk Forening for Estetisk Plastikkirurgi.

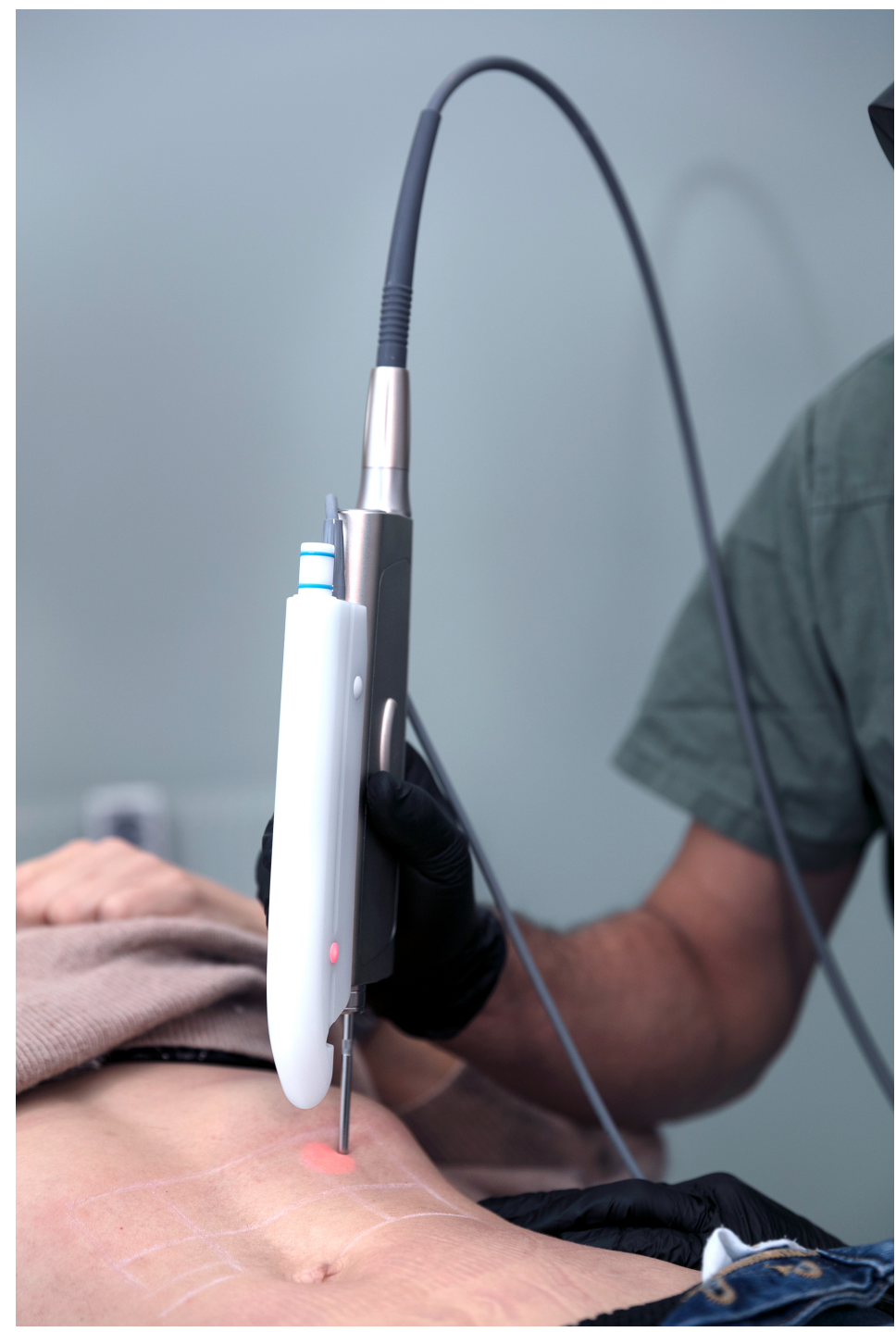


- Antallet studier på estetisk medisin som har livskvalitet som endepunkt, har økt siden 2010. De viser at estetisk medisin og kirurgi gir økt livskvalitet. Men dersom det dukker opp psykiske problemstillinger og du opererer på feil pasient, kan kosmetisk medisin gi en forverring. Det er derfor du må koble dette med kompetanse, sier Tvedt.

Tvedt har fulgt debatten om estetisk medisin med interesse. I en kronikk i Dagens Medisin etterlyser han en anerkjennelse av hvor mye et attraktivt utseende betyr for folks livskvalitet.

- I korrekthetens navn kan man ikke si at det er sånn det er. Men jeg etterlyser respekt for andres valg og respekt for andres plager. Noen mennesker har kjempeproblemer med utseendet og det legger begrensninger på livskvaliteten, sier Tvedt, og kommer med et eksempel:

- De som har store komplekser for nesen, for eksempel, vil passe på å ikke bli tatt bilde av, de vil unngå å bli sett i profil og de vil ha høye skuldre i sosiale sammenhenger. Vil de få bedre livskvalitet ved å bli kvitt det? Selvfølgelig, slår kirurgen fast.

Han mener bransjens rolle i å skape kroppspress er betydelig overdrevet. Han sier ikke at det ikke er en faktor i det hele tatt, men det avhenger av den enkelte klinikks markedsføring.

- I et samfunn der én av elleve reklamer går direkte på utseendet, blir det ikke riktig å kalle aktørene som driver med estetisk medisin for en hovedfaktor. Det er ikke herfra trykket kommer, argumenterer Tvedt.

\section{Et stort ansvar}

- Leger som velger å drive med estetisk medisin, tar på seg et stort ansvar. Det er i utgangspunktet friske personer de skal behandle. Da skal for eksempel risikoen for komplikasjoner være veldig liten, sier Svein Aarseth, leder for Rådet for legeetikk.

De behandlet klagen fra Vogt og Pahle høsten 2018. Etter to møter og én dissens ble rådets konklusjon at det ikke kan gis et generelt svar på spørsmålet som stilles. «Estetisk medisin er et vidt begrep, hvor det ikke kan trekkes en klar og generell grense mellom akseptabel og uakseptabel praksis», skriver rådet i sin uttalelse.

\section{Estetisk medisin}

Begrepet estetisk medisin eller kosmetisk medisin brukes om medisinske behandlinger der formålet er å oppnå en kosmetisk gevinst for pasienten. Estetisk kirurgi inkluderer for eksempel ansiktsløftninger og brystforstørrelser, mens estetisk medisin blant annet inkluderer injeksjoner av Botox og fillere.

Kilde: Tidsskriftet

- Samtidig er det et grunnleggende spørsmål som vi ikke har greid å svare på, innrømmer Aarseth:

- Er det greit for leger å gi en behandling bare fordi det er etterspurt? Leger i estetisk medisin er jo med på å definere hva som er «normalt». Som leger bør vi være bevisst på hva vi begir oss ut på når vi starter med denne typen behandling, sier Aarseth, og utdyper:

- Disse legene bidrar til å skape sitt eget marked. De skaper et behov og er gjennom sitt arbeid med på å definere hva som er pent og ikke. Det at en ting er tilgjengelig, kan være med på å normalisere det. Det tror jeg ikke man skal undervurdere. Jeg tror man må se at man er med på den utviklingen, når man jobber innen dette feltet, sier han.

At mange som får gjennomført prosedyrer, er fornøyd med resultatet, er ikke spesielt overraskende etter Aarseths oppfatning. 
-Spørsmålet er likevel: Bør en lege gjøre det?

- Hva mener du selv?

- Det er ikke min greie, for å si det sånn. Men det er ikke noe entydig svar på det.

\section{Komplikasjoner}

- Det er disse prikkene som plager deg?

Tilbake på kontoret snakker Sayed med mild stemme til en kvinne. For en tid siden oppsto det komplikasjoner etter at hun fikk behandling med plasmapen ved en annen klinikk. Beskjeden hun fikk, var at huden ville være helt bra igjen etter om lag ti dager. Men etter flere uker var prikkene der fortsatt.

Sayed forteller at det finnes tiltak. De kan for eksempel forsøke å behandle det overfladisk, med enten peeling eller laser. Men det aller beste er nok å vente litt og se om det går over av seg selv.

Det blir ikke bare enkelt. Etter en samtale og fotografering av hudskaden forteller kvinnen at hun ikke tør å gå ut i dagslys. Den siste uken har hun gjort alle ærender utenfor huset på kveldstid, etter at det har blitt mørkt, for at ingen skal se hvordan hun ser ut.

- Det er ikke spesielt synlig. Med det er det kanskje mange som har sagt det til deg, spør Sayed.

Kvinnen nikker.

Sayed følger opp med en rekke spørsmål om hvor stor plass utseendet tar i kvinnens hverdag. Ser hun seg mye i speilet? Tenker hun mye på hvordan huden ser ut? Etter en kort samtale, der han forsikrer henne om at han skal gjøre det han kan for å hjelpe henne nå, anbefaler han henne å droppe fremtidige behandlinger. Han tror ikke hun trenger det. Og dessuten:

- Når det er diskrepans mellom det man føler og hvordan man ser ut, er det ikke sikkert flere behandlinger hjelper. Da kan kognitiv terapi på 10-20 timer bedre dette veldig. Det er kanskje noe å tenke på? Det er ikke noe i veien med utseende ditt. Så hvorfor tar det så mye plass?

Les også: - Kosmetisk kirurgi er medisin

\section{Strengere regulering}

Ettersom private klinikker ikke har plikt til å rapportere hva de gjør, er det ingen som vet omfanget av estetisk medisin i Norge. De fleste Tidsskriftet har snakket med, ønsker seg en strengere regulering av feltet.

- I Norge er filler regulert av Mattilsynet. Det er absolutt helt uansvarlig. Slik fillerbehandlingen har utviklet seg, er det i praksis snakk om ansiktsimplantater. Det kan gi alvorlige komplikasjoner: Dersom man er så uheldig at man sprøyter filler i en blodåre, kan man få store hudskader. Er man ekstremt uheldig, kan pasienten bli blind, sier Tvedt.

I fjor skapte det store overskrifter da en klinikk valgte å tilby russerabatt på leppeforstørrelser. Tvedt frykter denne typen overtramp kan gi bransjen et omdømmetap. Derfor har han sammen med to sykepleiere og tre andre leger - blant dem Karim Sayed valgt å etablere en ny forening, som har fått navnet Norsk Forening for kvalitet i Estetisk Medisin (NORFEM).

- Målet er å skape en seriøs og kompetent bransje og lage et skarpt skille mellom den seriøse og useriøse delen av bransjen. Vi vil ha krav til behandlere, krav til klinikker og krav til etisk praksis, sier Tvedt.

Også Norsk plastikkirurgisk forening har satt i gang tiltak for å stramme opp bransjen. Etter en rekke medieoppslag om klinikker som drev med uetisk markedsføring, valgte 
foreningen høsten 2018 å oppdatere sitt etiske regelverk.

Regelverket slår blant annet fast at pasienter under 18 år, eller med kjente spiseforstyrrelser, ikke må tilbys kirurgi. I tillegg står det at det ikke skal forekomme gratiskonsultasjoner.

- Vi kan feie for egen dør. Vi har dessverre ikke mandat til å pålegge det store kosmetiske injeksjonsmarkedet tilsvarende etiske regler. Det må sentrale myndigheter gjøre. Vi ønsker derfor ikke at estetisk medisin og plastikkirurgi skal omtales som én stor sekk, men etterlyser strengere regulering også av den estetiske medisinen, sier Kjersti Ausen, leder for Norsk plastikkirurgisk forening.

Hun mener det er åpenbart at det ligger mye livskvalitet i å korrigere ting ved utseendet som plager en.

- Ett eksempel er brystrekonstruksjon etter kreft. Det handler i hovedsak om å normalisere utseendet, og alle er enige $\mathrm{i}$ at det er et offentlig anliggende. I gråsonen har man lyter og plager, som for eksempel strekkmerker etter fødsel, hvor kun de med vesentlige plager får offentlig korreksjon. I ytterkanten ligger det å optimalisere noe som allerede er normalt. Der ligger mange injeksjonsbehandlinger, mener Ausen, og legger til:

- Det som er spesielt med dette feltet, er at det kan brukes til både nyttige og unyttige ting. Det er en glidende overgang. Så hvor skal grensen gå?

\section{Vanskelige vurderinger}

Tilbake i Karl Johans gate står en kvinne med ryggen mot Sayed og viser frem det hun mener er litt for mye fett på flankene. De siste årene har hun gått ned ca. 15-20 kilo, men i det siste har hun gått litt opp igjen. Nå håper hun på en kickstart og at en laserbehandling skal kunne fjerne det fettet på nedre del av ryggen og på innsiden av lårene som hun ikke klarer å slanke bort selv.

- Det er ikke veldig mye fett her, da. Det er ikke det, sier Sayed. Det er for lite fett til å bli behandlet, synes jeg.

- Får jeg se hvordan det ser ut på innsiden av lårene? Der ser jeg du har litt irritert hud. Er det sånn at det gnisser? Har du vært plaget med eksem?

Til slutt lander Sayed på å ikke behandle flankene, men at det er greit å behandle lårene. Det er tre faktorer som gjør at Sayed vurderer det som riktig å gi henne denne behandlingen. Hun virker innforstått med hva den går ut på. Hun godtar det når Sayed forklarer henne at resultatet trolig ikke vil kunne bli perfekt og at hun kan få sideulikhet. Og hun har plager i form av rød og irritert hud.

- Sånne vurderinger er vanskelige. Men det er også det som gjør det interessant. Jeg kunne valgt å bare tenke i kroner og øre, men da ville jeg ikke fått sove om natten, sier han.

\section{Debatten fortsetter}

- Vi mener at Rådet for legeetikk ikke svarer på det viktigste spørsmålet vårt: nemlig hvordan legeprofesjonen skal forholde seg til at aktørene i feltet estetisk medisin skaper uhelse gjennom sin praksis og med det handler på en måte som er moralsk uforenlig med god legevirksomhet. Det skriver Andreas Pahle, Henrik Vogt og Petter Brelin, leder for Norsk forening for allmennmedisin, i en uttalelse til Tidsskriftet.

- Når det sentrale argumentet vårt ikke er besvart, så skjønner vi ikke hvordan verken vi eller tilhengere av estetisk medisin skal kunne bruke rådets svar den ene eller andre veien. 
De mener Nuffield Council on Bioethics' rapport som rådet viser til, har mange interessante poenger og i stor grad støtter deres syn på flere sentrale punkter.

- Men den svarer ikke på akkurat det vi spør om fordi den er rettet mot samfunnet generelt, og ikke legger spesielt vekt på leger som moralske aktører. Vi spør hvordan legeprofesjonen skal forholde seg til estetisk medisin, skriver de, og fortsetter:

- Rådet fortolker Nuffield-rapporten dithen at det ikke er mulig å skille akseptabel og uakseptabel praksis i feltet estetisk medisin. Dette er en feiltolkning av rapporten, etter vårt skjønn. Rapporten sier at det er vanskelig å dra helt klare grenser mellom terapeutiske inngrep og kosmetisk/estetisk medisin. Vi er enig at det kan være vanskelige grenseoppganger her, men tror ikke det vil være særlig vanskelig å identifisere aktører i denne virksomheten som kun driver med estetisk/kosmetisk medisin. Vi savner derfor at rådet sier noe prinsipielt om disse, utover at hver enkelt sak må vurderes for seg. Vi er av den oppfatning at når man skal vurdere enkeltsaker, så må man også ha prinsipielle føringer. Det ba vi rådet om, men fikk ingen, skriver de.

- Vi er av den oppfatning at Legeforeningen bør jobbe videre med denne saken. Den reiser helt fundamentale spørsmål om hva legeprofesjonen skal være.

Publisert: 25. februar 2019. Tidsskr Nor Legeforen. DOI: 10.4045/tidsskr.19.0114

(C) Tidsskrift for Den norske legeforening 2020. Lastet ned fra tidsskriftet.no 